\title{
Recontextualization of Orang-orang Installation Art Stage Set in Teater Di Sawah Padi Muzika Uda Dan Dara Performance
}

\section{Lena Farida binti Hussain Chin, Nadhilah binti Suhaimi}

To Link this Article: http://dx.doi.org/10.6007/IJARBSS/v11-i12/11730～DOI:10.6007/IJARBSS/v11-i12/11730

Received: 06 October 2021, Revised: 12 November 2021, Accepted: 30 November 2021

Published Online: 16 December 2021

In-Text Citation: (Chin \& Suhaimi, 2021)

To Cite this Article: Chin, L. F. binti H., \& Suhaimi, N. binti. (2021). Recontextualization of Orang-orang Installation Art Stage Set in Teater Di Sawah Padi Muzika Uda Dan Dara Performance. International Journal of Academic Research in Business and Social Sciences, 11(12), 2288-2298.

\section{Copyright: @ 2021 The Author(s)}

Published by Human Resource Management Academic Research Society (www.hrmars.com)

This article is published under the Creative Commons Attribution (CC BY 4.0) license. Anyone may reproduce, distribute, translate and create derivative works of this article (for both commercial and non0-commercial purposes), subject to full attribution to the original publication and authors. The full terms of this license may be seen at: http://creativecommons.org/licences/by/4.0/legalcode

Vol. 11, No. 12, 2021, Pg. 2288- 2298

Full Terms \& Conditions of access and use can be found at http://hrmars.com/index.php/pages/detail/publication-ethics 




\title{
Recontextualization of Orang-orang Installation Art Stage Set in Teater Di Sawah Padi Muzika Uda Dan Dara Performance
}

\author{
Lena Farida binti Hussain Chin, Nadhilah binti Suhaimi \\ Sultan Idris Education Univeristy, Malaysia \\ Email: lena.farida@fmsp.upsi.edu.my, nadsuhaimi11@gmail.com
}

\begin{abstract}
In theatrical staging, a stage set refers to the relationship between the stage arrangement and the representation that signifies an action. This substance refers to a representation that includes scenes used to identify the setting of a theatrical performance. At the same time, the art of installation is a three-dimensional work in the artistic genre whose display is often sitespecific. The purpose it was designed is to change the perception of space. From observing the Sawah Padi Muzika Uda dan Dara (TdSPMUD) theater performance that held at Padang Merbok Kuala Lumpur in 2019, many orang-orang were built to form a hybrid of installation art and make it part of a theater set. Therefore, this study focuses on synthesizing recontextualization between these two genres as scenic design construction. This study is a content analysis based on subjective reader-response theory to analyze the context of the displayed situation. The study results have shown that the relationship between installation art and the theatrical set has more significant theme considerations and the meaning of visual reflection. Overall, these ideas have contributed to the philosophical paradigm of Malaysian theater set design history.
\end{abstract}

Keywords: Performing Arts, Modern Theater, Environmental Theater, Malaysian Theater, Set Design, Installation Art, Scenography

\section{Introduction}

Empirical studies on the emergence of modern Malaysian drama emerged in the 1930s to date primarily devoted to the structure of acting and performance in terms of performance. Although many researchers have tried to look at form variance, the study is still text-based through available secondary references. Malaysian drama has begun to modify from traditional to modern forms. Presentation conventions of presentational style are converted into representations, and there is also a combination of the two. According to Ahmad (2000), there is no in-depth study in drama. Experimental Malay drama increase thrives subsequent years that passed in the 1980s and 1990s. Husin (2010) stated that there was a significant increase in the use of Malay performing arts by experimental theater in the context of diversity, critical applications, processing approaches, and roles played compared to the dramatic TEM texts produced in the 1970s. This improvement gives a different experimental 
style to the intensively applied text compared to the existing experimental text. It is named a folk experiment. This study discusses the discourse of dramatic structural processes that produce new values in text building structures.

The birth of printed scripts marked the beginning of modern Malaysian drama because the machinery symbolized modernity. It begins with the realism era when many young Malays who returned from overseas bring together ideal thought for transforming society. The history of modern Malaysian drama is fascinating because it moves in line with the political strings in Malaysia. This matter is due to the ideology of young writers who reflect political developments into their work. Realism in Malaysia openly criticizes government policies through social and family issues with comedy and tragedy techniques.

According to Zuhra (1992), national independence impacts the response of stage playwrights to national development. As the era of nationalism left a strong imprint on the drama of the 1950s, the impact of independence was portrayed through the writer's focus on developing realistic drama themes and styles in the 1960s. After the country achieved independence in 1957, the energy of the new nation was directed towards the process of nation-building. For that, national goals become more specific and diverse. The First Malaysia Plan was created as the initial phase of the twenty-year plan (1965-1970), emphasized the future orientation of Malaysia's new leadership.

Through their script, Zuhra sees the Modern playwright supporting the idea of national development but clearly expressing their concerns about the developments under the right values and attitudes. The author reminds many that conflicting social values need carefully assessed and resolved so that the social fabric of their new country does not deteriorate in the course of Malaysia's development. Their concern for the community is the integrity and success of the new nation.

In the 1960s, Indonesian and Western-stage drama was influenced by a stream of realism that offered a direct and intelligible medium. It aims to communicate ideas relevant to their community by initiating the practice of realistic mode. One of the first exemplary realistic dramas was Di Balik Tahir Harapan written and directed in 1960 by Mustapha Kamil Yassin. Krishen Jit argues, by 1963, Modern drama had been at the forefront Malaysia's modern drama movement in which love is no longer a driving force in French theater. After observing three accumulated drama performances in 1963, he concluded Awang Had Salleh's realistic social drama titled Buat Menyapu Si Air Mata, Mustapha Kamil Yassin's classic Modern drama entitled Atap Genting Atap Rumbia, and the drama Sial Bertuah by Kalam Hamidy. Sial Bertuah was one of the most popular dramas of the 1960 s, first staged at a drama festival in Singapore. After 1963, theater representation has become a dominant force in the playwright's stage in decades of Malay (Zuhra, 1992). Since then, modern drama terns race with the state of national development and current social issues. The main goal of the ham government is expanding access to education, especially for rural Malays. He stressed again, and they stand as a group that has been under education during the colonial era. Teachers and students are the same characters in Modern drama. In a typical modern drama plot, a teacher or prospective graduate will decide to serve the people in a rural area because the educational needs in the area are high. These themes support the government's efforts for educational and rural development.

Following the 1969 riots, the transformation of modern Malaysian drama began to take off. Symbolism in modern drama has become a starting point in Malaysia. Noordin Hassan wrote Bukan Lalang Ditiup Angin (BLDA) to criticize the government loudly but not openly. From there, writers in Malaysia began to experiment and prefer to criticize Malaysian 
politics through works. At the same time, the works of realism terns produced in their form until the emergence of neorealism, absurdism, and even experimentalism that triggered various issues and ideologies.

\section{Background of the Study}

In the middle of the century, modern Malaysian theater was associated with art through social change. However, by the end of the nineteenth century, the terminology of l'art d'avant-garde was aligned with cultural and artistic problems. Since then, the trend of increasing emphasis on this aesthetic issue has continued to this day. Avant-garde today generally refers to intellectuals, writers, artists, and culturalists voicing ideas by experimenting through artistic approaches that challenge current cultural values. These avant-garde ideas encompass social issues assimilated by society (Porter, 2004).

Consequently, the term avant-garde now refers to experimental, radical, and unorthodox people or works concerning art, a culture that encompasses society. Avant-garde forms are characterized by aesthetic innovations that push to the limits of what is accepted as the norm or status quo, especially in cultural arts. In this regard, Dinsman's existence in Malaysian avant-garde theater cannot be denied. The figure in this genre is still active from the beginning in the 1970s until now. In addition to writing plays, poems, short stories, and cultural essays, he is also active as a political writer and publishes books and documentary series (Dinsman, 2009). Among his works of art that can be categorized as avant garde art are Protes (1972); Jebat (1973); Diri (1974); Ana (1976); Sadandi (1977); Izie (1982); Pokok (2017) and the latest is the direction of Teater di Sawah Padi Muzika Uda dan Dara (2018 and 2019).

The selection of Usman Awang's masterpiece, Muzika Uda dan Dara, is specifically suitable in this experimentation which is in line with the purpose of avant-garde art. Muzika Uda dan Dara was published in 1976 by Dewan Bahasa dan Pustaka. This drama tells the story of the conflict of social oppression of the paddy community oppressed by the tyranny of a land leech named Alang Bakhil (Dara's uncle) who has pawned the land of the poor farmers. Due to the poverty factor, Uda and Dara's love becomes complicated because Dara's family hinders it. In that series, Uda took himself to the city to hunt for wealth to have Dara. After succeeding, Uda returned to the village to fulfill his promise to Dara while redeeming the mortgaged lands. However, Alang Bakhil remained reluctant and did not want to accept Uda due to differences in background and family lineage. Eventually, Uda was killed in a pact that caused Utih to rise and develop the fighting spirit of the villagers to defend the fate of the farmers and fight against the tyranny of land leeches.

According to Ishak (1987), a contemporary form of Malay drama produced in the postindependence period has highlighted the events based on scenarios reflecting social and political debate in Malaysia. This study shows that the authors' minds are susceptible to the country's development and policy, which is of concern. The situation showed that social imbalances had caused such issues to be a voice through drama scripts. The cries of issue from the writers at the time carried the orang-orang ${ }^{1}$ who criticized the lame policies. Indirectly, this has directly reflected on the politics and leadership of the country. Not only that, Sikana (1985) explained that the issue is quite fundamental in a drama when the work

${ }^{1}$ According to Kamus Dewan $4^{\text {th }}$ Ed. Orang-orang is an imitations of people, puppets, and statues: 2. a statue made to scare birds. Orang-orang is a scarecrow. According to Cambridge Dictionary scarecrow is a model of a person dressed in old clothes and put in a field of growing crops to frighten birds away. 
discusses the concept of justice, definition of humanity, human responsibility to God, self, society, and religion, and the struggle against tyranny and try to uphold justice. To date, the main issues and themes highlighted in this drama are still relevant. This masterpiece, which is over 40 years old, has all the formulas mentioned by Ishak, S. and Sikana, M. to this day, Uda and Dara Music is still fresh, and its principal theme is still going on to this day, albeit in a different form. Land leeches continue to breed, and the proletariat continues to be oppressed prey.

Initially, this theater wanted to be set up and staged at Usman Awang's birthplace in a village house in Kuala Sedili. According to Dinsman 2017 in the Tekad Budaya Akhbar Amanah column, "The idea arose when I thought of Kuala Sedili and then went there in early 2015 , looking at a place to hold a program to appreciate Usman Awang's humanitarian poems, which we call Hening Puisi. That's when the idea came to my imagination. What if the Muzika Uda dan Dara theater by Usman Awang was staged in his hometown, in a village, and in a simple way. Without referring to the script for details, I imagine the theater will be made in a courtyard of a village house, without much preparation in stagings. "(Dinsman, 2019). However, this is not the case due to several unavoidable factors and problems. Finally, the idea of staging has changed to another place, namely at the edge of a paddy field in Sungai Besar in 2017. In a staging, Dinsman think about the differences and the impact of theater on society. Thus, the paddy fields were the best option at that time, aiming to elevate this theater to the most appropriate space for the spectacle of community groups in the setting and story set. Muzika Uda dan Dara tells the story of the struggle of the peasant community, and this theater is a gift for them (art for the community).

The theater was flooded with nearly two thousand spectators on each night of the show. Seeing this success, the KL International Arts Festival 2018, Datin Sunita Rajakumar, has asked Dinsman to stage it again in Kuala Lumpur. However, due to technical and space problems, the demand could not be met in 2018 but instead became a reality in 2019 when KL Diversity, Ministry of Agriculture and Agro-based Industry, Universiti Pendidikan Sultan Idris, and several other ministries and agencies also became co-organizers for the successful staging in Padang Merbok, Kuala Lumpur. Finally, this staging became a reality when it was successfully staged on 25 and 26 October 2019. TdSPMUD has created its history in Malaysia's modern theater as the largest environmental theater ever staged.

This theater performance developed on an area of 1 acre equivalent to 43560 square feet. The purpose is to create a village atmosphere after the harvest. Around it, 100 orangorang have been set up as installation art that is part of this theatrical set. In environmental theater, theater not only acts as a complex social canvas, but it is a network of hopes, attention, and struggles from artists to society. The exchange of stimuli for space or ideology is a significant root of this genre (Schechner, 1968). Suderburg (2000) explained:

Installation is the noun form of the verb to install, the functional movement of placing art in the "neutral" void of a gallery or museum. Unlike earthworks, it initially focused on institutional art spaces and public spaces that could be altered through "installation" as an action. "To install" is a process that must take place each time an exhibition is mounted; "installation" is the art form that takes note of the perimeters of that space and reconfigures it. The ideological impossibility of the neutrality of any site contributes to the expansion and application of installation, where sculptural forms occupy and 
reconfigure not just institutional space but also the space of objecthood.

Shanks and Pearson (2001) also explain how permanent and temporary arrangements for this genre should be carefully planned because these arrangements involve actors and audiences no longer conventionally like performances in stage and stage spaces. For your information, the environmental theater is not a popular genre in Malaysia. This genre is considered trivial and troublesome. Therefore, a large number of theater performances in Malaysia are only staged in conventional theaters. According to orang-orang history, its primary function was to scare away pests from eating crops. Farmers and ranchers usually build orang-orang in rural agricultural and plantation landscapes. In the different cultural contexts of other countries, there are many rituals associated with making orang-orang on farms and plantations. Yet, with the advancement of civilization characterized by engineering nowadays, orang-orang are no longer used. Now it is almost disappearing from the rural landscape (Krol et al., 2019). In Malaysia itself, orang-orang are no longer a well-known monument, but it is an odd thing. Realizing the extinction of the orang-orang and its function, the oppression theme of the peasantry in Usman Awang's drama has raised the concept of the orang-orang as a symbolic and representative of the proletariat struggle oppressed by the bourgeoisie.

The motivation of this study was conducted to look into the latest developments of avant-garde work of theatre design and scenography in Malaysia. The Uda and Dara stage performance was used as a sample because of its largest environmental theatre that focuses on site-specific performance that integrates stage set development using installation art. In Malaysia, most theatre performances are only staged in conventional stages such as proscenium and arena. Environmental theatre that focuses on site specifics is not a medium of choice as it involves high costs, complicated bureaucracy management, and risky implementation due to the unpredictable equatorial weather factors of the year. Thus, this big staging performance scale is seen as a shift of taking the risk to place the development of avant-garde theatre to a more dynamic level, especially in Malaysia. The contribution of this study demonstrates that the market and social exploration of environmental theatre and sitespecific is possible for Malaysian theatre. Theatre activists must have the courage to provide accurate and precise information on the needs and attitudes in their work because theatre performance plays an important social role, encouraging Malaysian theatre workers in developing responsive services, policies, and products to identify the needs throughout the challenges.

\section{Methodology}

The qualitative content analysis is applied in an inductive or deductive way. Both inductive and deductive content analysis processes involve three main phases: preparation, organization, and reporting of results. The preparation phase consists of collecting appropriate data for content analysis, understanding the data, and selecting the unit of analysis. The organizational phase includes open coding, category making, and abstraction (Elo \& Kyngäs, 2008). In this research, researchers use inductive reasoning. Inductive reasoning begins with specific observations or actual examples of social events, trends, or processes. Using these data, the researcher then advanced analytically to generalize the theory more broadly aimed at helping clarify the observed cases by subjective readerresponse theory for analyzing the context of perceived situations (Bleich, 2019). Reader response critiques argue that literature should be seen as a performing art in which each 
reader makes a presentation related to their text that may be unique. To create an analysis, I used recontextualization as a process for visual reading (set design context). Recontextualization is the process of extracting a text, sign, or meaning from its original context (decontextualization) and reusing it in another context. Since the meaning of a text, sign, and content depend on its context, recontextualization implies a change of meaning and redefinition. For this purpose, I have chosen the intratextual principle to see the new context and add a new meaning to it.

\section{Synthesizing a Set of Contextualization Achievements and Installation Art}

TdSPMUD this time promises a twist. This production combines three generations of actors under one commonality. Among the main actors who succeeded in TdSPMUD were Dato 'Rahim Razali as Utah, Aiman Nazmi as Uda, Amirah Razak as Dara, Roslan Madun as Poet, Ruzaidi Abd Rahman as Pak Guru, Nadhilah Suhaimi as Ibu Uda, Ayudez Zuraina as Mak Dara, Roydy Rokidy as Alang Bakhil, Yassinsalleh as Pak Tua, Nizam Yamin as Lebai and the unique appearance of Indonesian Musicalization stars, namely Qori Islami Aris and Syahfitra Harahap. This staging is presented on a site-specific basis in an environmental theater group without state intervention. The space is clear as a magical realism that fits the whole idea of the show as something impossibility filled with irony, symbolism, and playfulness but very serious. In an environmental theater performance, theater not only serves as a complex social network, but it is also a network of hopes, obligations, and struggles from artists to society. Whether sensory or ideological, the exchange of stimuli is a primary root of this genre (Schechner, 1968). Shanks and Pearson (2001) explained how permanent and temporary arrangements for this genre should be well planned because arrangements involving actors and audiences are no longer conventional like performances in a shared space, i.e., stage. Space will be manipulated in various ways by applying crowd control techniques because the experience for each spectator is different, involving time of attendance, activities, positions having multiple times and focuses. Audience control is difficult, especially when it involves open and large spaces. Realizing this, selecting a specific site medium for theater is not an easy task to realize.

It requires careful planning, and a large amount of expenditure is required to embody that imagination. Various researches have been done in that direction, such as paddy cultivation, paddy field care, and transportation and maintenance logistics to transform an artificial paddy field in Kuala Lumpur. The production team also seeks advice from various parties on the matter. However, the expense required is very high as it involves a variety of specialties. Several alternative options are also discussed to replace the paddy fields, including straw as a substitute for background. When the agreement was agreed, the organizers finally sponsored several paddy straws (including logistics and maintenance) to be used as the backdrop of the paddy field village, which at that time DBKL had not yet decided on the approval of the required space despite several meetings. After months of meeting to find answers, Dinsman finally agreed to embody the field's dimensions from a different perspective, namely the background of the field after the harvest. Despite the various obstacles and challenges faced, finally, Padang Merbok has become the space of choice for this historic staging.

Next, after examining a few things from an artistic point of view, the concept of installation art was chosen to spearhead the scenographic design. According to Petersen (2015), concurrent with installation art's business with reality is its business with unreality, given that installations include staged images, fiction, and situations. In short, they deal with 
the scenic arts of theatre and performance. When viewers enter an installation, they enter the "scene" of the artwork. Installations are not self-sufficient, autonomous entities, but stages are laid out around viewers for their benefit. In the words of conceptual artist Joseph Ko, an installation "constructs its own 'event context' for the viewer's experience. This concept was chosen to compose a perception of space that can be interpreted with various conceptual dimensions belonging together, creating a relationship between writers, artists, artists, and audiences. Next, this mega set was developed on a field space of 1 acre, which is equivalent to 43560 square feet, to embody the ambiance of a paddy field village after the harvest. At the beginning of the planning, green paddy fields were an option to fill this space. However, this intention had to be modified according to the current situation. Some positions had to be modified to look at the suitability of the viewing dimensions. Of course, it is not an easy job in addition to various conditions imposed on production. Among them is that space is limited with the condition at the last minute not to go beyond the rugby field, located in the middle of the field. This situation makes it difficult to establish the background settings created while purchasing raw materials has been made. The situation hampers all early planning which will have a major impact on the continuity of planning. However, all these risks were fully borne by Dinsman and TdSPMUD Publisher M. Nasser Mohamed by giving the green light to happiness installation art concept was chosen to lead the landscape design at TdspMUD. This chosen concept was intended to structure perceptions of space that could be interpreted with various conceptual dimensions of co-ownership, establishing a relationship between the writer, the artist, and the audience. This mega set was developed on 1-acre equivalent to 43560 square feet to create a rice field village atmosphere after harvest with 100 orang-orang installed. The sense of smell and tactile connect the smell and taste of the village after harvest to the audience. This artistic design tells a visual story and traces the main philosophy of this performance (Chin, 2020). As we have seen, the context of orang-orang as the art of installation highlights the emphasis of the avant-garde.

According to Rosenthal et.al (2003), modern installation artists turn out to be, in principle, how to reflect the experience of life reflecting its complex issues, aspects, and appearances. Thus, the installation technique has proved to be a valuable tool to speak about and investigate life rhetorically. On the other hand, losnesco \& Pronko (1963) stated that the avant-garde is the underlying artistic and cultural phenomenon. Thinkers and artists express the avant-garde by using modified forms to reinforce the latest forms in several things, including ideological, artistic, or social. The philosophical determination between performance sets and the art of installation has developed a deeper meaning. This recontextualization of emerging landscape forms demonstrates the intertextuality of design, bringing the whole concept to be experimental and radical. Craft art is a tribute to the field of art itself and the culture that encompasses society. This unique feature of aesthetic innovation leads to the limits accepted as the norm or status quo, especially in cultural arts.

\section{Metaphors of Orang-orang and Orang in the Performance of Related Texts}

Dinsman, in his imagination, has imagined a magnificent paddy field in the heart of the city of Kuala Lumpur. This dedication meant for all city dwellers and tourists can enjoy the village nature, which increasingly swallowed by development, and this magical has become a reality even the gift of unceasing rain from God strengthens the relationship between olfactory and tactile senses of smell and taste of the village after the harvest to the audience. All the staff on duty complete the craftsman's work in the rain, storm, and heat alternately at night and day. This artistic design tells a story about the visuals and traces the philosophy and the 
senses, so when looking at the results and effects, it is a work of art that is very valuable to all the workforce. According to Koijck et al (2015), many odors can stimulate the olfactory system and trigeminal system. Thus, trigeminal nerve activation can evoke haptic sensations related to the sense of touch, particularly those related to the perception and manipulation of objects using touch and perception or awareness of position and movement. This regulation represents a tactile taste that provides a stimulus attribute to various tastes.

This taste reflection may have 1001 stories and differ from each audience's perspective according to their experience on the night of the show. Some gave unique responses about their childhood experiences growing up in paddy fields. These audience are delighted because they have been away from the nostalgia buried in their minds for so long. While some spectators responded that it was less pleasant because they were not familiar with the strange smell of mud-coated straw, surrounded by flying straw birds and even had to step on and sit through the rough texture of it. They felt that this was an extraordinary experience. Some spectators did not have this experience but enjoyed the moment of the atmosphere, and they stated that it was an incredible experience. Some audiences are even accustomed to watching theater in an air-conditioned stage environment with comfortable chairs using formal attire to watch. Magically, those with high heels and lightning shoes also rode together to watch this theater in the drizzle, wearing ponchos and umbrellas. What is essential, Padang Merbok has managed to connect spectators from various walks of life with no less than thousand spectators on each night of performances from various states, and some came from Indonesia, Thailand, and Singapore (Lena Farida Hussain Chin, 2020). Even more excited when $80 \%$ of the audience waiting in the rain until the end of the performance. This phenomenon is an extraordinary history for Malaysian theater. Whatever their reflection on TdSPMUD's performance, that is a gift from TdSPMUD brought to Malaysian theater fans.

The installation of the orang-orang at TdSPMUD provides a symbol in opposing the collapse of human civilization in the modern world today. As we know, the role of orangorang in agriculture is usually to keep pests away from eating crops. Orang-orang are usually displayed in the village landscape and serve the farmers. There are also many rituals associated with the making of orang-orang on farms and plantations. In this theater, the function of the orang-orang is more valuable than the antagonistic character who shows abysmal value. The stage set emphasizes a dramatic background, but when the background is raised in the form of installation art, the meaning can change, and this was not conceptualized to change the perception of the space. Perceptual transformation brings more significant influx and his ability to physically interact with the audience, not just on the night of the show. While all art mediums can engage individuals, most do not fully engage them in interactive experiences.

This result is symbolic of the critique of the strong, who are often pests to the helpless proletariat (peasants). Well, the number of orang-orang installed shows a metadiscursive increase in drama themes. In this theater, the romance between the two degrees, namely Uda \& Dara, is no longer the main question, but the priority is how the proletariat wakes up to fight the tyranny of a land leech named Alang Bakhil (the main antagonist). In TdSPMUD, Alang Bakhil symbolizes middle-class characteristics, usually considered a materialistic person with a conventionally dominant attitude of a patriarch. In addition, the proliferation of meaning occurs when the characters in TdSPMUD antagonist effect wears traditional costume while orang-orang are in modern dress. The points show the contradiction between good and bad things aim to reinforce the contextualization of the meaning of visual expansion. In this case, even though orang-orang are inanimate and do not have the power of thought, its 
function overcomes the advantages of thinking that exist in humans. Humans feel comfortable with the meaning of representative binary resistance, but the assessment of assumptions is still also punished by visual interpretation. This metaphorical contradiction emphasizes the reversal of unconscious thought, which is often dominated by the assumption of conscious thought. Thus, the ridicule orang-orang were interpreted as the spirit of truth that stands firm with the struggling proletariat oppressed by the bourgeoisie.

In TdSPMUD, the orang-orang installation also provides a symbol in opposing the collapse of human civilization in today's modern world. Orang-orang functions are more valuable than antagonistic characters who show immoral values. This result is a critique of the powerful, who are often pests to the helpless proletariat. The installation of orang-orang and jamung is not just a cosmetic that colors TdSPMUD, but it is a work of art that refers to the basics of needs and goodness in life. When translating an artistic work for theater, the main thing that should be emphasized is the framework of the study and the conceptual meaning of the design. From the moment, the meaning is essential to define the proportion of a resulting art. In this case, as a directly involved observer and reviewer, the findings and responses of the audience that were outside the process were very satisfying. Responses found that various labels were given. Some like it, some are excited, some are mediocre, some don't like it, criticism, and so on. Some even say it's a waste. But it does not matter because the significant sponsorship does not come in cash flow but in the form of materials and necessities that, on average, provide employment and income to the proletariat group as well, which consists of farmers, drivers, cleaners, craftsmen, and artists. However, that is the acid of salt in the world of art. TdSPMUD is not just to satisfy the appetite, but its magic is a creative axiom towards its main goal in educating and elevating the function of Malaysian literature, art, and theater to the eyes of the world without social margins in between.

\section{Conclusion and Benefit to the Nation}

Through this analysis, we can see how installation art can play an essential role in enhancing the meaning of theatre performance. The theatrical set stands on the concept of art construction of the setting and stands as a pillar of art that joins the great theme of this drama. In my observation, during the day, the average visitor who came to view this art installation-built village had no idea about the theater performances at night. They don't even care about the theater set available and the acting space. Instead, they are more interested in taking pictures with the set with these orang-orang. Not only taking pictures, they even started asking about the purpose of construction and demonstration, about the concept of paddy fields after the harvest, and what most interested them was the installation of orangorang accompanied by jamungs. Through the demonstration of this mega art installation, I found that the present visitors were so excited to see the village atmosphere in the paddy fields after the harvest season in the middle of a rapidly developing city. They were excited, and it was never affordable to see this atmosphere brought so close to them. From not being a theater enthusiast, various questions were asked about the purpose and knowledge of the art of this installation. As a result, they began to know about theater and were so excited to watch it at night. However, facing the day turns to night stimulates the function of the art of installation's meaning. The art of this installation has changed to accompany the social and life themes. Then came recontextualization as a process for visual reading in the theatrical and life context. This perception has gone through decontextualization which plays a role in developing symbolic themes from the art of installation to the story of the presentation in a unique setting. The combination of theatrical set and installation art has expanded the 
intratextual to look at different contexts by integrating the relationship between writer, artist, and audience, thus adding new meaning and discourse in this fictional result.

\section{References}

Bleich, D. (2019). Subjective criticism. Maryland: John Hopkins University Press.

Dinsman. (2017). Mengapa perlu pentaskan lagi Uda dan Dara? (Tekad budaya). Kuala Lumpur: Akhbar Amanah.

Elo, S., \& Kyngäs, H. (2008). The qualitative content analysis process. Journal of Advanced Nursing, 62: 107-115. DOI: 10.1111/j.1365-2648.2007.04569.x

Husin, F. (2007).Teater eksperimental Melayu: Satu kajian bentuk dan struktur teks dramatik. Kuala Lumpur: Dewan Bahasa dan Pustaka.

Ionesco, E., \& Pronko, L. (1963). Notes on my theater. The Tulane Drama Review, 7 (3), $127-$ 159. DOI: $10.2307 / 1125090$

Chin, L. F. H. (2020). Magis avant garde dan seni instalasi dalam Teater di Sawah Padi Uda dan Dara. Kuala Lumpur: Majalah Pentas. (ISBN 1823-9943. Jil.14 Bil. 1 JanuariDisember 2020, Pg34 - 39)

Sikana, M. (1985). Mendekati drama. Selangor: Penerbitan Sarjana (M) Sdn Bhd.

Ahmad, M. N. (2000).Seni persembahan drama Melayu moden. Bangi, Selangor: Penerbit Universiti Kebangsaan Malaysia.

Zuhra, N. N. (1992). An analysis of modern Malay drama. Shah Alam: Biroteks, MARA Institute of Technology.

Petersen, A. R. (2015). Installation Art between image and stage. Copenhagen: Museum Tusculanum Press.

Rosenthal, M. (2003). Understanding installation art: from Duchamp to Holzer. London: Prestel Publishing.

Schechner, R. (1968). 6 Axioms for environmental theater. The Drama Review: TDR, 12 (3), 4164. DOI: $10.2307 / 1144353$

Shank, P., \& Pearson, M. (2001). Theater/archeology. New York: Routledge.

Suderburg, E. (2000). Space, site, Intervention: Situating installation art. Minneapolis: University of Minnesota Press.

Ishak, S. (1987). Histrionics of development: A study of three contemporary Malay playwrights. Kuala Lumpur: Dewan Bahasa dan Pustaka.

UKEssays. (2018). Importance of set design theater essay. Retrieved from https://www.ukessays.com/essays/theatre/importance-of-set-design-theatreessay.php?vref $=1$ 